\title{
Islam in the Nordic and Baltic Countries (Islamic Studies Series) \\ Göran Larsson, ed.
} Oxon, UK and New York: Routledge, 2009. hbk. 147 pages

Until recently, scholarly writing on Islam in the Nordic and Baltic regions has proved to be a woefully scant enterprise. Most works that have emerged on the topic of Islam in Europe focus on the United Kingdom and France, leaving northern and eastern European regions largely underanalyzed. It is in this respect that Göran Larsson's edited volume is to be welcomed as an important and long overdue contribution to the topic.

The volume is comprised of nine chapters, which are an overall survey of Islam and Muslim communities in the Nordic and Baltic regions. In chapter 2, "The Faroe Island and Iceland," Göran Larsson and Ingvar Svanberg maintain that Muslims in the Faroe Islands and Iceland are best characterized as a virtually invisible religious and cultural minority. Compared with the Faroe Islands, Iceland is a more open society for Muslims, who have organized a functioning center in Reykjavik. Although religious freedom is upheld in the Faroe Islands and Iceland, Christianity is prevalent, and there are a small number of Muslims in these countries (16).

In chapter 3, "Regarding Islam in Norway," Christine Jacobsen maintains that Norway is divided into a multiplicity of religious discourses, which Muslim people orient to in order to represent their religious identities. The Muslim population in Norway is estimated to be 120,000 out of a total population of 4.5 million. Jacobson briefly explains that up until the 1990s, the main direction in Norway's institutionalization of Islam was the establishment of mosques and organizations along national lines. However, new patterns of cooperation among Muslims in Norway have yielded a more ambitious nationwide Islamic presence. Jacobson sees heterogeneous, dynamic, and emerging configurations of Islam in Norway. For example, although Muslims are a visible group in the eastern city of Oslo, they have remained largely invisible in the western city of Bergen.

While chapter 2 is relatively short with spare documentation, chapter 3 is documented thoroughly. In chapter 4, Garbi Schmidt discusses the presence of Muslims in Denmark. The development of Islam in Denmark reveals a general move away from Muslim ethnic affiliations toward questions of how and if Muslims should engage in broader society. Schmidt wonders whether the Danish debate on Islam and Muslim communities is 
moving toward efforts at national reconciliation. Unlike the contributions on Norway, the Faroe Islands and Iceland, Schmidt includes reflections on this national discussion of Islam, but she only discusses Islamic institutions briefly.

Göran Larsson writes in chapter 5 about Sweden and indicates that even Muslims are becoming more visible in the Swedish public sphereand that Islamophobia, discrimination, and segregation are clearly discernible. In order to provide a more comprehensive picture of Islam in Sweden, he suggests that it is imperative to study the more fluid category of "secular" and "cultural" Muslims (70). It would have been interesting if Göran Larsson had expounded on those categories more thoroughly. The chapter contains an adequate number of references for further research on Islam in Sweden. In chapter 6, Tuomas Martikainen writes that Muslims in Finland have a similar history as those in Sweden. Muslims in Finland (comprising 1 percent of Finnish society) face severe economic difficulties. Martikainen's presentation is convincing; however, he fails to clearly identify other problems in Muslim communities and to offer suggestions for their solutions. Although Martikainen mentions the most prominent aspects of Islam's development in Finland, he does not go into details.

The final three chapters of the book focus on the Baltic region-namely, Estonia, Latvia, and Lithuania. The history of the Muslim presence in Estonia dates back to the sixteenth century. Aysha Özkan writes in chapter 7: "The experience of being Muslim in secular Estonia" is "not difficult" because Muslims are "not really visible," owing to the reality that they are regarded as Others. In contemporary Estonia, language rather than religious affiliation is the cause of discriminations toward Muslims living among the Russian-speaking minority (99). However, Aysha Özkan does not provide details of the living conditions in the Muslim communities. In chapter 8, Emin Poljarevic and Ingvar Swanberg write about Latvia, contending that although Islam also has a long history, it is marginalized as it is in Finland and Estonia. The Muslim community in Riga and elsewhere is divided along ethnic lines. The authors include clear information and an insightful history of Muslims in Latvia from before 1917 to the present. Egdūnas Račius maintains in chapter 9 that Lithuania has opened up to the world only recently, and deals with its own problems concerning the constitution of the population in relation to Lithuania's various faiths and traditions. According to Račius, Lithuania is heading toward the presence of Muslim communities in its country, but Muslims that are responded to with antagonism (129). Račius suggests a sympathetic approach to the dif- 
ficult circumstance in which Muslims find themselves and the importance of the availability of sympathetic scholarly articles about Islam and the Muslim community in Lithuania.

Readers of Islam in the Nordic and Baltic Countries can face difficulty in understanding individual essays in this collection in relation to a broader picture of Islam and Muslim communities in the Nordic and Baltic regions. The lack of precise theory and methodology remains a further weakness of this contribution. In this regard, the discussion of notions of the "collective identity" (national vs communal) and the multiple formations that impact the reality of "self" and "other" could have provided interpretive coherence for these articles. Following analyses of socioeconomic problems and the rise in unemployment in Muslim communities (specifically in Finland and the Baltic region), theories of "subjectivity" could have helped the reader understand how such sociological changes affect shifts in the construction of identity. A focus on interviews and the use of techniques of participant observation might have helped the reader examine the everyday lives of Muslims in the discussed countries and situated them in the broader discussion of Muslims and Islam in Europe in regard to the specific differences of Muslim communities.

In summary, while the difficulty of editing and constructing a study comprising a series of contributions from multiple academic authors is appreciated, the book suffers from a lack of detailed analyses of Muslim communities in the Nordic and Baltic region. That said, the volume is an extremely welcome addition to available resources and provides a variety of interesting perspectives on a particular region. It has the potential to be a pivotal reference work for scholars of history and all researchers interested in Islam and Muslim communities in northern Europe and the Baltic region.

Fatemeh Shayan

Doctoral Candidate in International Relations, School of Management/Political Science and International Relations, University of Tampere, Finland, Staff member at Isfahan University. fatemeh.shayan@uta.fi 